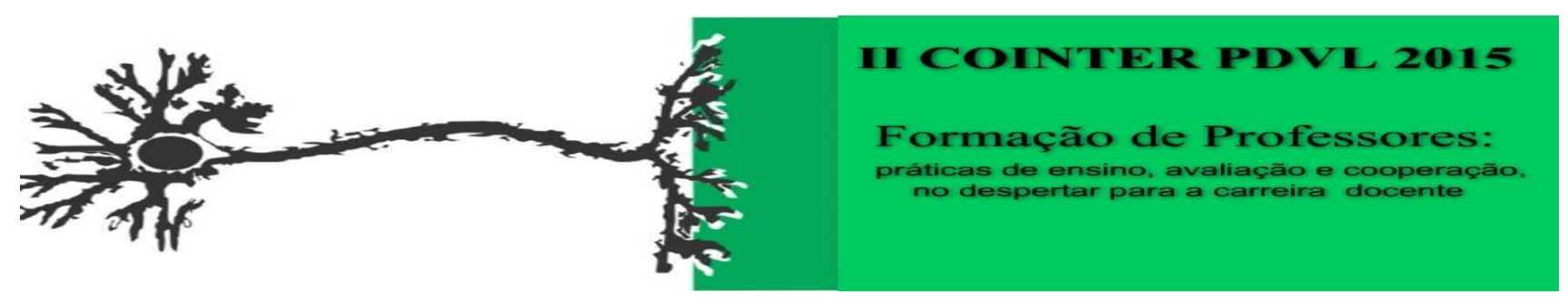

\title{
ESTÁGIO SUPERVISIONADO EM ESPAÇOS NÃO FORMAL: POSSIBILIDADES DE INTERVENÇÃO PEDAGÓGICA
}

\author{
Apresentação: Relato de Experiência \\ Priscilla do Carmo ${ }^{1}$; Luciene Santos $^{2}$; Maria Valquíria ${ }^{3}$.
}

\section{Introdução}

Pensar a educação como processo não linear, contínuo, que envolve diferentes intenções de atores diversos, implica também entendê-la numa dimensão de amplitude, que se materializa em espaços formais, com intencionalidades anunciadas, mas também acontece em espaços que nem sempre se apercebem que estão imersos num processo formativo. Neste sentido, Brandão (2007) afirma que:

\begin{abstract}
A educação existe onde não há a escola e por toda parte pode haver redes e estruturas sociais de transferência de saber de uma geração a outra, onde ainda não foi sequer criada a sombra de algum modelo de ensino formal e centralizado, porque a educação aprende com o homem a continuar o trabalho da vida. [...]. Brandão (p.13).
\end{abstract}

Assim sendo, é possível pensar a pedagogia como ciência que nos fornece elementos para pensarmos o processo educativo, mas também como teoria que imbrica pensado e vivido na formação de sujeitos capazes de pensar suas escolhas. $\mathrm{O}$ pedagogo por sua vez, tem na docência escolar, sua base identitária, porém seu campo de atuação profissional se estende a outros espaços que suscitam intervenções pedagógicas, no sentido de construir intencionalidades para o processo de ensino/aprendizagem. Libâneo (2005) pontua que: "não se trata de desvalorização da docência, mas de valorização da atividade pedagógica em sentido mais amplo, no qual a docente está incluída". (p.40).

Diante do exposto, como objetivo deste trabalho intencionamos apresentar um relato de experiência do componente curricular de Estágio Supervisionado em espaços educativos não formais. A experiência foi vivenciada por estudantes da licenciatura em Pedagogia da Faculdade Osman Lins - FACOL / Vitória de Santo Antão - PE.

\section{Relato de Experiência}

O componente curricular de Estágio Supervisionado II, inicia propondo aos estudantes a

\footnotetext{
${ }^{1}$ Mestre em Educação - UFPE/CAA. Professora Substituta da UFPE/CAV. Professora da Licenciatura em Pedagogia, Faculdade Osman Lins - FACOL, priscillacarmopontes@hotmail.com

${ }^{2}$ Graduanda em Pedagogia, Faculdade Osman Lins - FACOL. Kaio.kaka@hotmail.com

${ }^{3}$ Graduanda em Pedagogia, Faculdade Osman Lins - FACOL. Da.vil.25@hotmail.com
} 
leitura dos estudos de Brandão (2007), Libâneo (2005), Pimenta (2011), Cunha (1989) dentre outros. Posteriormente, eles realizam fichamentos e mapas conceituais a fim de sistematizar as leituras. Nesta atividade de aproximação dos conceitos fomos identificando os elementos constitutivos da profissionalidade ${ }^{4}$ do pedagogo.

Os estudantes, em acordo com a professora/orientadora do Estágio Supervisionado, são lotados nos devidos espaços para o início das observações e atividades de regências. Os espaços não formais que acolheram os estudantes para a realização desta atividade foram: hospitais, centro de referência de assistência social - CRAS, casa de idosos, ONGs, casa de crianças, museu do município e brinquedoteca.

O público com os qual, os estudantes da licenciatura trabalharam durante o estágio foi: crianças hospitalizadas, dependentes de álcool, dependentes químicos, menores em situação de risco, mães que estão acompanhando seus bebes na Unidade de Tratamento Intensivo, idosos que moram em instituições filantrópicas, pessoas com necessidades educativas especiais, alunos de escola regular que estavam visitando o museu.

As atividades realizadas estiveram ligadas ao fortalecimento de vínculos familiares e comunitários, planejamento de projetos didáticos, oficinas de leitura e escrita, incentivo a leitura de poesias, contos e outros gêneros textuais.

\section{Considerações}

Durante a realização desta vivência, o processo de ensino/aprendizagem, pôde ser problematizado, pelos estudantes da licenciatura em Pedagogia, em contextos diversos, atendendo a um público, por vezes, a margem do processo de escolarização, mas que sinaliza o desejo por aprender e ensinar. Evidenciamos também a aproximação da faculdade com a comunidade local, atendendo a demandas muitas vezes silenciadas no espaço acadêmico.

\section{Referências}

BRANDÃO, Carlos Rodrigues. O que é educação. São Paulo: Brasiliense, Coleção Primeiros Passos, $28^{\mathrm{a}}$ ed.1993.

LIBANEO, J. Pedagogia e Pedagogos para quê? São Paulo: Cortez, 2005.

\footnotetext{
${ }^{4}$ A profissionalidade é por nós tomada a partir de Sacristán (1999) como a profissão em movimento, o específico que o profissional realiza no contexto de seu trabalho.
} 